\title{
EVALUASI DIAGNOSTIK LESI ENDO-PERIO YANG MENETAP SETELAH PERAWATAN ENDODONTIK MENGGUNAKAN RADIOGRAFI PERIAPIKAL DAN CBCT
}

\author{
Novi Kurniati*, Azhari** \\ *Departemen Radiologi Dental, Fakultas Kedokteran Gigi, Universitas Prof. Dr. Moestopo (Beragama), Jakarta \\ **Departemen Radiologi Kedokteran Gigi, Fakultas Kedokteran Gigi, Universitas Padjajaran, Bandung. \\ Korespondensi: Novi Kurniati, ms.novikurniati@gmail.com
}

\begin{abstract}
ABSTRAK
Latar Belakang: radiografi periapikal dua dimensi merupakan pemeriksaan yang sering dipergunakan untuk mengevaluasi hasil perawatan. Kelemahan inherent seperti superimposed, distorsi dan tidak dapat menampilkan lesi dari berbagai aspek membuat para dokter sulit untuk mendapatkan informasi yang sesuai keadaan yang sebenarnya karena keterbatasan radiograf dua dimensi. Pencitraan CBCT dapat menyediakan informasi yang relevan yang tidak ditemukan dalam radiografi periapikal.Laporan Kasus: pasien laki-laki berusia 38 tahun dengan keluhan utama gigi insisivus sentral rahang atas yang berubah warna karena trauma 10 tahun yang lalu. Pasien dirujuk untuk dilakukan radiografi periapikal, di mana tampak gambaran lesi radiolusen berbatas jelas di apikal disertai resorbsi internal gigi 11, dengan diagnosis granuloma periapical et causa nekrosis pulpa gigi 11. Setelah dilakukan perawatan 2 bulan dilakukan evaluasi I dengan radiografi CBCT, tampak tampak lesi radiolusen berbatas jelas dan tegas berukuran $\pm 3,6 \mathrm{~mm}$ di apikal serta adanya perforasi sisi mesial akar gigi yang menyebabkan lesi radiolusen di sisi mesial gigi 11 disertai perforasi kortikal di tulang daerah palatal. Enam bulan kemudian dilakukan evaluasi II menggunakan radiografi periapikal dan CBCT. Pada radiografi periapikal tampak, lesi radiolusen berbatas jelas dan tidak tegas di apikal gigi. Pada radiografi CBCT tampak lesi radiolusen berbatas jelas yang telah mengecil di apikal, namun lesi di bagian mesial dan perforasi kortikal tulang palatal belum terjadi penyembuhan secara signifikan. Berdasarkan hasil radiografi CBCT, pasien di rujuk ke bagian Periodonti.Kesimpulan: pemeriksaan CBCT sangat diperlukan pada evaluasi perawatan kasus kompleks untuk mendapatkan informasi diagnostik yang lebih akurat.
\end{abstract}

Kata kunci: CBCT, granuloma, periapikal, periodontal

\begin{abstract}
Background: two-dimensional periapical radiography is an examination that is often used to evaluate the results of treatment. Inherent weaknesses such as superimposition, distortion and cannot display lesions from various aspects make it difficult for doctors to obtain information that fits the actual situation due to the limitations of $2 D$ radiography. CBCT imaging can provide relevant information not found in periapical radiographs. Case Reports: a 38-year-old male patient with a complaint of maxillary central incisors who had discolored trauma 10 years ago. Patients were referred for periapical radiographs, where the radiolucent lesion appeared well-defined border in the apical area accompanied by internal resorption in tooth 11, with a diagnosis of periapical granulome et causa necrosis pulp of tooth 11. After 2 months of treatment I was evaluated with CBCT radiography, radiolucent lesions appeared. clear and firm borders measuring $\pm 3.6 \mathrm{~mm}$ apically and perforation of the mesial side of the tooth root causing radiolucent lesions on the mesial side of 11 teeth accompanied by cortical perforation in the palatal bone region. Six months later evaluation II was performed using periapical radiography and CBCT. On periapical radiographs it appears, radiolucent lesions are well-defined at apical teeth. On CBCT radiographs, clear and indistinct radiolucent lesions appear that have narrowed apically, but lesions in the mesial and cortical perforations of the palatal bone have not been significantly healed. Based on CBCT radiographic results, patients were referred to the Periodontics section Conclusion: CBCT examination is very necessary in evaluating complex case care to obtain more accurate diagnostic information.
\end{abstract}

Keywords: CBCT, granuloma, periapical, periodontal

\section{PENDAHULUAN}

$\mathrm{L}$ esi inflamasi periapikal didefinisikan sebagai respon lokal dari tulang di sekitar puncak akar gigi yang terjadi sebagai akibat dari nekrosis pulpa atau kerusakan jaringan periapikal oleh penyakit periodontal yang luas. ${ }^{1,2}$

Lesi inflamasi periapikal adalah merupakan salah satu alasan yang paling sering untuk di- 
lakukan evaluasi menggunakan pencitraan dalam rutinitas klinik gigi. Evaluasi dini status periapikal diperlukan tidak hanya untuk diagnosis tetapi juga untuk perawatan dan tindak lanjut. Untuk tujuan perencanaan perawatan, diperlukan informasi luasnya lesi, jumlah akar, dan saluran akar di gigi yang terkena, keterlibatan selektif akar oleh lesi, dan dalam beberapa kasus yang diindikasikan operasi periapikal, informasi tentang hubungan antara apeks akar, lesi dan fitur anatomi jaringan sekitar sangat penting untuk diketahui. ${ }^{2}$

Perencanaan perawatan yang akurat adalah bagian penting dari endodontik. Pencitraan diagnostik membantu dokter untuk memvisualisasikan anatomi gigi di daerah yang tidak bisa terlihat secara klinis. Evaluasi jaringan periapikal pada perawatan endodontik, memungkinkan dokter untuk mendiagnosis penyakit, untuk melihat perkembangan atau regresi penyakit dan menilai hasil perawatan. ${ }^{3}$

Radiografi memainkan peran penting dalam keberhasilan atau kegagalan dari diagnosis dan manajemen perawatan endodontik. Hal ini disebabkan oleh fakta bahwa interpretasi radiografi dapat mempengaruhi kesuksesan atau kegagalan perawatan endodontik. Namun, karena kelemahan inheren seperti superimposed struktur anatomi, distorsi geometrik dan anatomic noise menyebabkan sulit untuk mendeteksi lesi periapikal pada radiografi dua dimensi (2D) ${ }^{3-5}$ Lesi periapikal pada radiografi dua dimensi hanya bisa terdeteksi saat kehilangan mineral tulang telah mencapai 30\% $-50 \%$ hal ini akibat adanya noise dari tulang kortikal yang superimposed. Karena itu, hanya 50-55\% lesi berukuran kecil dan sedang dapat didiagnosis sebagai penyakit periapikal., ${ }^{4,5}$

Baru-baru ini sebuah modalitas pencitraan baru, cone-beam computed tomography (CBCT), telah diperkenalkan dan telah terbukti bermanfaat dalam sejumlah aplikasi. Hasil diagnostik gambar CBCT dikatakan lebih unggul dibandingkan dengan radiografi periapikal dan informasi yang diperoleh dari hasil pemindaian ini terbukti bermanfaat dalam perawatan klinis perencanaan dan pengambilan keputusan. ${ }^{4,6-8}$

\section{LAPORAN KASUS}

Pasien laki-laki berusia 38 tahun dengan keluhan utama gigi insisivus sentral atas yang berubah warna karena trauma 10 tahun yang lalu. Pada pemeriksaan intraoral, tampak gigi 11 berubah warna dan sakit pada saat diperkusi (Gambar 1). Untuk membantu menegakkan diagnosa, pasien dirujuk untuk dilakukan radiografi periapikal.
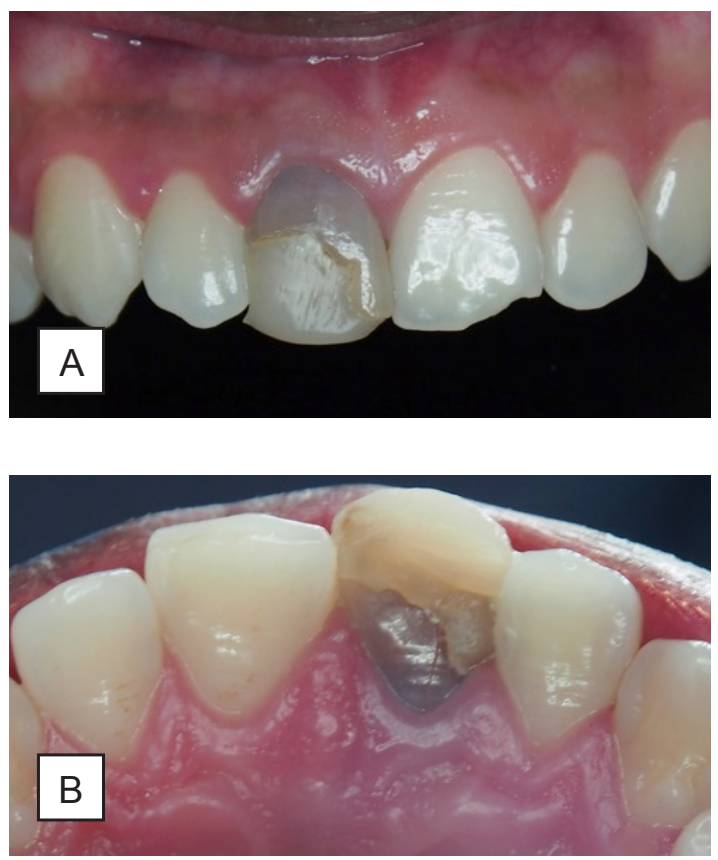

Gambar 1. Gambaran klinis gigi 11 sebelum perawatan berubah warna dari arah labial (a), dan palatal (b)

Pada radiografi periapikal (Gambar 2), tampak gambaran lesi radiolusen berbatas jelas di apikal disertai resorbsi internal gigi 11. Suspek radiodiagnosis dari gambaran radiograf periapikal tersebut adalah granuloma periapikal et causa nekrosis pulpa gigi 11 .

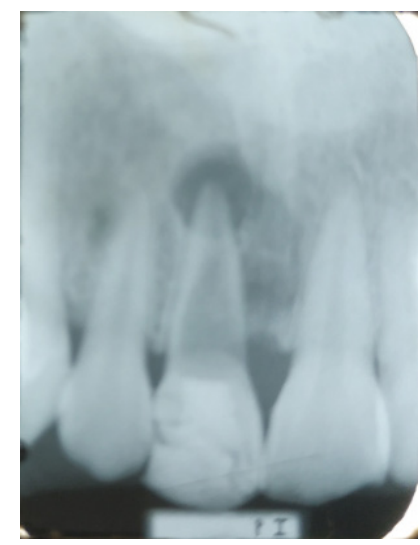

Gambar 2. Radiografi periapikal (diagnosis) menunjukkan gambaran lesi radiolusen dengan batas jelas di apikal disertai resorbsi internal gigi 11

Setelah dilakukan perawatan 2 bulan dengan Kalsium hidroksida $(\mathrm{CaOH} 2)$ dan Mineral trioxide aggregate (MTA) dilakukan evaluasi I dengan radiografi CBCT (Gambar 3), tampak lesi radiolusen berbatas jelas dan tegas berdiameter $\pm 3,6 \mathrm{~mm}$ di apikal serta adanya perforasi sisi mesial akar gigi 11 yang menyebabkan lesi radiolusen di sisi mesial gigi 11 disertai perforasi kortikal di tulang daerah palatal. 

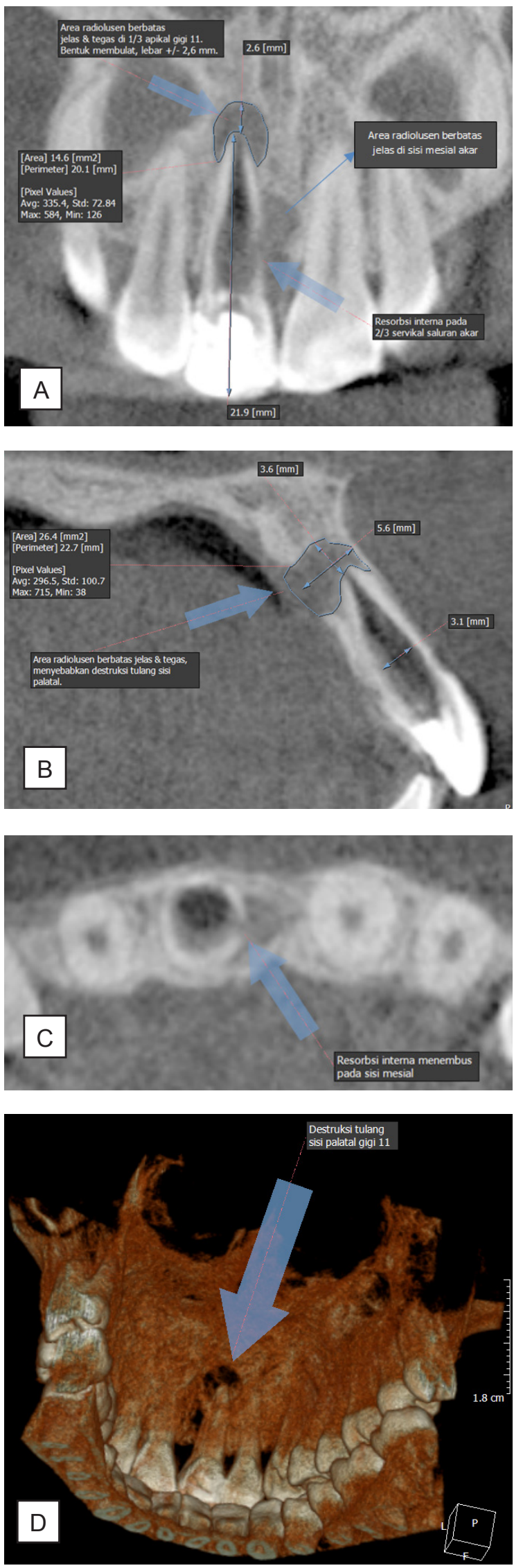

Gambar 3. Radiografi CBCT (evaluasi I). (A) Koronal, lesi radiolusen berbatas jelas dan tegas berdiameter $3,6 \mathrm{~mm}$ di apikal, perforasi sisi mesial akar gigi 11 dan radiolusen berbatas jelas di sisi mesial gigi 11. (B) Sagital, perforasi kortikal di tulang daerah palatal. (C) Aksial, menunjukan resorbsi internal dan perforasi pada akar gigi 11 sebelah mesial yang menyebabkan radiolusen di sisi mesial gigi 11. (D) Gambaran 3D, menunjukkan destruksi tulang di sisi palatal dan radiolusen di sisi mesial gigi 11.

Enam bulan kemudian dilakukan evaluasi II menggunakan foto gambaran klinis gigi 11 (Gambar 4), radiografi periapikal dan CBCT. Pada radiografi periapikal (Gambar 5) tampak, lesi radiolusen dengan batas jelas dan tidak tegas di apikal gigi 11. Pada radiografi CBCT (Gambar 6) tampak lesi radiolusen berbatas jelas dan tidak tegas yang telah mengecil di apikal, namun lesi di bagian mesial dan perforasi kortikal tulang daerah palatal belum terjadi penyembuhan secara signifikan. Berdasarkan hasil radiografi $\mathrm{CBCT}$ ini, pasien dirujuk ke bagian Periodonsia.

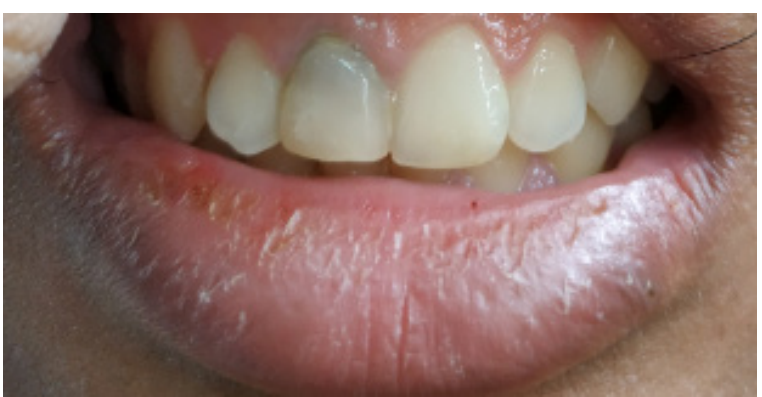

Gambar 4. Gambaran klinis gigi 11 setelah perawatan selama 6 bulan

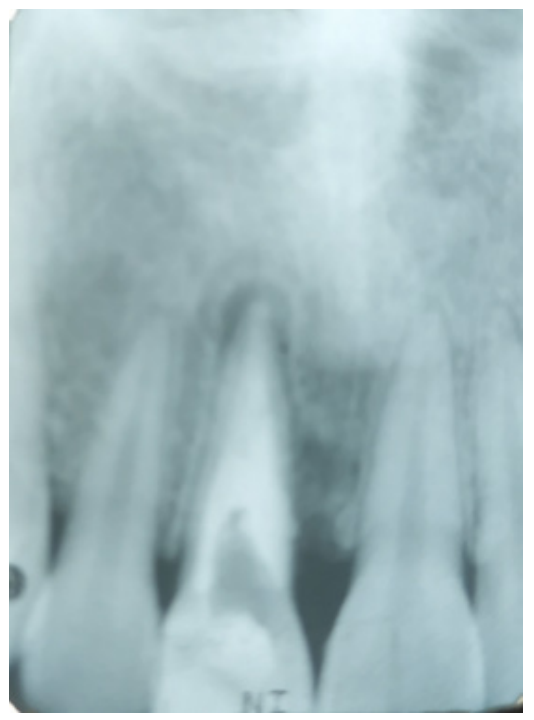

Gambar 5. Radiografi periapikal (evaluasi II) menunjukkan gambaran lesi radiolusen dengan batas jelas dan tidak tegas yang telah mengecil di apikal gigi 11. 

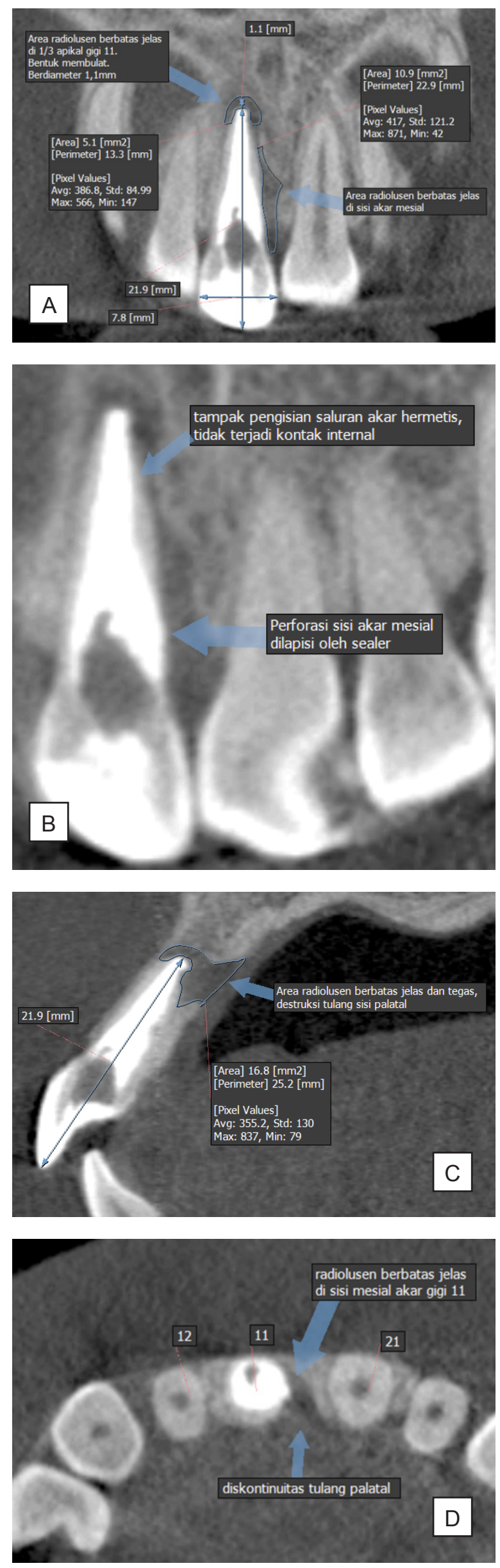

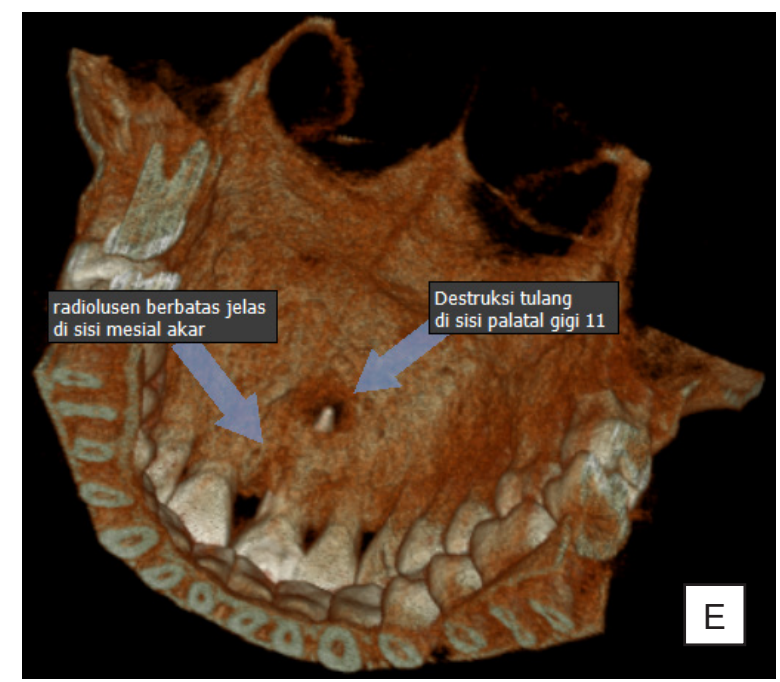

Gambar 6. Radiografi CBCT (evaluasi II). (A)

Koronal, lesi radiolusen berbatas jelas dan tidak tegas berdiameter $1,1 \mathrm{~mm}$ di apikal dan radiolusen berbatas jelas di sisi mesial gigi 11. (B). Saluran akar telah diisi secara hermetis, sehingga tidak terjadi kontak internal. (C) Sagital, perforasi kortikal di tulang daerah palatal. (D) Axial,menunjukkan radiolusen di sisi mesial gigi 11 dan destruksi tulang di palatal. (E) Gambaran 3D, menunjukkan destruksi tulang di sisi palatal dan radiolusen disisi mesial gigi 11

\section{PEMBAHASAN}

Pencitraan radiografi memainkan peran utama dalam pendeteksian kelainan tulang pada tulang rahang. Terdapat beberapa faktor penting dalam pendeteksian lesi pada berbagai teknik pencitraan seperti lesi, ketebalan dan derajat mineralisasi tulang di sekitarnya, geometri iradiasi, dan resolusi sistem pencitraan. Radiografi intraoral periapikal adalah representasi bidimensional dari struktur tridimesional. ${ }^{9}$ Beberapa faktor seperti kepadatan tulang, kontras radiografi, angulasi, evaluator, dan perpanjangan dari lesi dapat mempengaruhi kemampuan mendeteksi keberadaan lesi periapikal ketika radiografi periapikal digunakan sebagai alat diagnostik. Selain itu, lesi periapikal yang dibatasi oleh tulang cancellous tidak mudah dideteksi dengan radiografi dua dimensi. ${ }^{9,10}$

Meskipun radiografi intraoral adalah pemeriksaan diagnostik yang berguna dan biasanya direkomendasikan, interpretasi gambar-gambar ini mungkin tidak memberikan informasi yang akurat bagi banyak orang. Literatur telah menunjukkan bahwa lesi periapikal yang berada pada tulang cancellous sering tidak terlihat sampai lesi mulai mengikis lempeng kortikal. ${ }^{6}$ Selain itu, Bender dan Seltzer, 1961 (dalam Ordinola-zapata R et al, $2011^{9}$ dan Rai A et al, 2016 ${ }^{2}$ menggambarkan prinsip-prinsip dasar yang terlibat dalam mendeteksi keropos tulang pada lesi resorptif lokal menyimpulkan bahwa karena kandungan mineral yang rendah pada tulang meduler, lesi resorptif berukuran besar sulit terdeteksi lebih 
lanjut pada radiografi periapikal., ${ }^{2,9}$ Temuan serupa telah dilaporkan oleh Schwarz dan Foster,1971(dalam Rai A et al, $2016^{2}$ dan Pascual J et al,2015 ${ }^{11}$ ), Lee dan Messer, 1986 (dalam (dalam Rai A et al, $2016^{2}$ ), dan Wallace et al, 2001 (dalam Rai A et al, 2016²). Selain masalah kemampuan deteksi, Eickholz dan Hausmann, 2000 (dalam Rai et al, 2016²) menunjukkan bahwa penilaian radiografi menggunakan radiografi periapikal cenderung mengabaikan jumlah kehilangan tulang sebesar 1,41 hingga 2,58 mm. ${ }^{2}$ Penulis lain seperti Shoha et al,1974; Scarfe et al,1999 dan Marmary et al,1999 (dalam Rai A et al, 2016²) juga menyetujui bahwa ukuran lesi periapikal sering diabaikan dalam radiografi periapikal. ${ }^{2}$ Hal ini sesuai dengan radiografi periapikal pada kasus ini yang hanya menunjukkan gambaran lesi radiolusen berbatas jelas di apikal disertai resorbsi internal gigi 11 tanpa bisa menunjukkan adanya resorbsi tulang alveolar dan ukuran linear dari besar lesi. (Gambar 2).

Cone - beam CT (CBCT) yang mulai diperkenalkan pada tahun 2000 memungkinkan pencitraan tiga dimensi (3D) dari jaringan keras di volume kecil rahang. ${ }^{2}$ CBCT menyediakan gambar tiga dimensi yang memungkinkan visualisasi lengkap dari suatu area, baik dilihat dari bidang aksial, sagital maupun koronal. ${ }^{6}$ CBCT dapat mengatasi beberapa keterbatasan dari radiografi konvensional. Misalnya, hubungan spasial dari akar gigi yang multiple bisa divisualisasikan dalam tiga dimensi serta ukuran sebenarnya dan sifat dari lesi periapikal juga dapat dinilai menggunakan teknologi CBCT. Teknologi CBCT membantu diagnosis kelainan endodontic, fraktur akar dan alveolar, penilaian morfologi kanal, analisis lesi resorptif, identifikasi lesi patalogis asal non-endodontik, evaluasi persiapan pengisian saluran akar dan serta penilaian pra-bedah yang diperlukan untuk operasi endodontik. .,6,8,10 $^{-10}$

Keuntungan lain dari CBCT adalah kemampuan untuk menunjukkan potongan yang direkonstruksi yang menghindari tulang kortikal melalui penggunaan perangkat lunak khusus. Wu et al,2009 (dalam Ordinola-zapata $\mathrm{R}$ et al, 20119 ). membahas pengaruh CBCT untuk penelitian masa depan yang melibatkan keberhasilan atau kegagalan perawatan endodontik menggantikan radiografi periapikal yang memiliki keterbatasan dalam menampilkan kerusakkan tulang yang sesuai dengan keadaan jaringan periapikal yang sebenarnya. Penelitian baru menegaskan informasi dan menunjukkan bahwa daerah resorpsi dapat terlihat lebih jelas menggunakan potongan CBCT dibandingkan dengan radiografi periapikal yang menunjukkan adanya superimposed pada tulang sehingga membatasi tampilan perluasan radiolusen dalam radiograf periapikal. ${ }^{9}$ Hal ini didukung oleh beberapa penelitian yang membandingkan penggunaan pencitraan volumetrik tiga dimensi (3D) dan pencitraan dua dimensi (2D) pada kerusakan tulang buatan yang menunjukkan bahwa CBCT memiliki sensitivitas 80-
$100 \%$ dalam mendeteksi dan klasifikasi kerusakan tulang, sementara intra oral radiografi memiliki sensitivitas 63-67\%. ${ }^{12}$ Pada kasus ini dapat dilihat pada radiografi CBCT (Gambar 3a,b,c,d) yang dapat menunjukkan perforasi kerusakan tulang periapikal secara tepat dibandingkan dengan radiografi periapikal (Gambar 2).

Stavropoulos et al, 2007(dalam Gusiyska A, $2015^{10}$ ). telah menunjukkan bahwa CBCT memiliki sensitivitas yang lebih tinggi, sehingga memberikan diagnosis yang lebih tepat daripada radiografi intraoral dalam menilai keberadaan destruksi tulang. Sekitar 50\% dari kasus, teknik CBCT memungkinkan para dokter mendiagnosis lesi pada tulang yang tidak dapat dideteksi oleh metode radiografi intraoral. ${ }^{10} \mathrm{CBCT}$ juga memungkinkan visualisasi perubahan ukuran lesi karena pembentukan tulang endosteal baru. ${ }^{5}$ Hasil penelitian ini juga menunjukkan bahwa CBCT adalah metode yang dapat diandalkan untuk mendeteksi penyembuhan lesi periapikal setelah perawatan saluran akar, menunjukkan perubahan tulang periapikal dalam interval waktu yang sebentar (perbandingan antara Gambar 3A dan 4A).

CBCT juga dapat digunakan untuk menentukan sifat lesi periradikular. Simon et al, 2007(dalam Estrela et al, 2008 ${ }^{8}$, Gusiyska A, $2015^{10}$ dan Pascual $\mathrm{J}$ et al, 2015 ${ }^{11}$ ). telah mengeksploitasi potensi CBCT untuk membedakan antara lesi solid, lesi berisi cairan atau lesi berisi jaringan. ${ }^{8,10,11}$ Mereka menemukan bahwa teknologi CBCT dengan menyesuaikan kontras dapat membantu dalam diagnosis banding sehubungan dengan diagnosis yang lebih spesifik dari lesi endodontik periapikal, baik kista maupun granuloma. ${ }^{10}$

Deteksi perforasi akar penting untuk mendapatkan obturasi optimal pada perawatan endodontik dan dalam kasus pengisian retrograd selama operasi periapikal. Deteksi perforasi akar dapat dilakukan dua kali lebih cepat pada CBCT. Komunikasi marginal akar gigi bisa berhubungan dengan lesi endo-perio dan menandakan pentingnya terapi periodontal pada gigi dengan komunikasi marginal. ${ }^{9}$ Pada kasus ini dibuktikan adanya komunikasi marginal pada akar gigi yang menyebabkan radiolusen di sisi mesial akar gigi 11 terlihat pada radiograf CBCT (Gambar 3A dan C). Enam bulan kemudian mulai terjadi penyembuhan lesi periapikal dan periodontal setelah saluran akar dilakukan pengisian secara hermetis (Gambar 6B), walaupun penyembuhan lesi periodontal (Gambar 6A) dan penyembuhan tulang kortikal palatal (Gambar 6C,D, dan E) yang terjadi kurang signifikan sehingga berdasarkan hasil radiografi CBCT ini pasien dirujuk ke bagian Periodonsia. Semua temuan menunjukkan keakuratan CBCT sebagai pencitraan tiga dimensi untuk diagnosis, perencanaan perawatan, dan operasi apikal. 


\section{KESIMPULAN}

Sebagai kesimpulan, kasus ini menyoroti peran CBCT untuk diagnosis dan perencanaan perawatan lesi periapikal. Visualisasi 3D dari lesi ini menawarkan keuntungan lebih dari modalitas pencitraan 2D. Gambaran sebenarnya dari destruksi osseus dari lesi periapikal dan periodontal dapat dideteksi secara akurat menggunakan CBCT. Pemeriksaan CBCT sangat diperlukan pada evaluasi perawatan kasus kompleks untuk mendapatkan informasi diagnostik yang lebih akurat.

\section{DAFTAR PUSTAKA}

1. White SC, Pharoah M. . Oral Radiology and Interpretation. 7th ed. St.Louis: Elsevier; 2005.

2. Rai A, Burde K, Guttal K, Naikmasur VG. Comparison between cone - beam computed tomography and direct digital intraoral imaging for the diagnosis of periapical pathology. 2016. doi:10.4103/2321-3841.196346

3. Venskutonis T. Periapical tissue evaluation: analysis of existing indexes and application of Periapical and Endodontic Status Scale ( PESS ) in clinical practice. $G$ Ital Endod. 2016;30(1):14-21. doi:10.1016/j. gien.2016.04.002

4. Balasundaram A, Shah P, Hoen MM, et al. Comparison of Cone-Beam Computed Tomography and Periapical Radiography in Predicting Treatment Decision for Periapical Lesions: A Clinical Study. 2012;2012. doi:10.1155/2012/920815

5. Khetarpal A, Chaudhary S, Sahai S. Radiological assessment of periapical healing using the cone beam computed tomography periapical index: case report. $2013 ; 9(5): 46-51$.
6. Pratyusha M V, Nadig P, Jayalakshmi KB, Math S. CBCT assessment of healing of a large radicular cyst treated with enucleation followed by PRF and osseograft placement : A case report. 2017;(21):72-76. doi:10.21276/sjodr.2017.2.3.4

7. Gambarini G, Piasucki L, Miccoli G. Cone-beam computed tomography in the assessment of periapical lesions in endodontically treated teeth. 2018. doi:10.4103/ejd.ejd_320_17

8. Estrela C, Bueno MR, Azevedo BC, Azevedo JR, Pécora JD. A New Periapical Index Based on Cone Beam Computed Tomography. 2008;34(11):1325-1331. doi:10.1016/j.joen.2008.08.013

9. Ordinola-zapata R, Bramante CM, Duarte $\mathrm{MH}$, Fernandes MPSR. The influence of cone-beam computed tomography and periapical radiographic evaluation on the assessment of periapical bone destruction in dog ' s teeth. YMOE. 112(2):272-279. doi:10.1016/j. tripleo.2011.01.031

10. Gusiyska A. Cone Beam Computed Tomography in the Diagnosis of Chronic Apical Periodontitis and Clinical Decisions : A Review. 2015;4(2):1655-1659.

11. Pascual J, Abella F, Morales K, Duran-sindreu F, Roig M. ScienceDirect Endodontic applications of cone beam computed tomography : case series and literature review Applicazioni della tomografia computerizzata a fascio conico in Endodonzia: G Ital Endod. 2015;29:38-50. doi:10.1016/j.gien.2015.08.002

12. Kumar V, Arora K, Udupa H. Journal of Oral Hygiene \& Health Different Radiographic Modalities Used for Detection of Common Periodontal and Periapical Lesions Encountered in Routine Dental Practice. J Oral Hyg Heal. 2014;2(5). doi:10.4172/2332-0702.1000163 